\title{
INTEGRATIVE REVIEW: BEHAVIORAL INTERVENTIONS FOR PHYSICAL ACTIVITY PRACTICE
}

\author{
Thaís Moreira Spana ${ }^{1}$ \\ Roberta Cunha Matheus Rodrigues ${ }^{2}$ \\ Laura Bacelar de Araújo Lourenço ${ }^{3}$ \\ Roberto Della Rosa Mendez \\ Maria Cecília Bueno Jayme Gallani ${ }^{2}$
}

Spana TM, Rodrigues RCM, Lourenço LBA, Mendez RDR, Gallani MCBJ. Integrative review: behavioral interventions for physical activity practice. Rev Latino-am Enfermagem 2009 novembro-dezembro; 17(6):1057-64.

This study aimed to carry out an integrative literature review on the effectiveness of interventions in physical activity (PA) practice in the general population. The search was carried out in articles indexed in online databases: Scopus, CINAHL and Medline. Studies in English or Brazilian Portuguese were included, with evidence levels 2 or 3, published between 2004 and 2008. The final sample consisted of 14 studies. In 57.1\% of the studies, interventions were effective for behavior change to practice PA. The diversity of target populations, assessment instruments and intervention designs makes it difficult to compare results and build evidence on the effectiveness of interventions for PA promotion.

DESCRIPTORS: motor activity; behavior; intervention studies

\section{REVISIÓN INTEGRATIVA: INTERVENCIONES COMPORTAMENTALES PARA REALIZACIÓN DE ACTIVIDAD FÍSICA}

Este estudio tuvo como objetivo realizar una revisión integrativa de la literatura sobre la efectividad de intervenciones en la realización de Actividad Física $(A F)$ en la población general. La búsqueda fue realizada en los artículos on line indexados en las bases de datos Scopus, Medline y Cinahl. Fueron incluidos estudios en lengua inglesa o portuguesa de Brasil, con nivel de evidencia 2 o 3, publicados entre 2004 y 2008. La muestra final fue compuesta por 14 estudios. En $57,1 \%$ de los estudios las intervenciones fueron efectivas para realizar cambios de comportamiento relacionados a la AF, sin embargo, pocas fueron basadas en teorías. La diversidad de las poblaciones objetivo, de los instrumentos de evaluación y de las intervenciones, dificulta la comparación de los resultados y la construcción de evidencias sobre la efectividad de intervenciones para la promoción de $A F$.

DESCRIPTORES: actividad motora; conducta; estudios de intervención

\section{REVISÃO INTEGRATIVA: INTERVENÇÕES COMPORTAMENTAIS PARA REALIZAÇÃO DE ATIVIDADE FÍSICA}

Este estudo teve como objetivo realizar revisão integrativa da literatura sobre a efetividade de intervenções na realização de Atividade Física $(A F)$ na população geral. A busca foi realizada nos artigos on line indexados nas bases de dados Scopus, Medline e Cinahl. Foram incluídos estudos em língua inglesa ou portuguesa do Brasil, com nível de evidência 2 ou 3, publicados entre 2004 e 2008. A amostra final foi composta por 14 estudos. Em 57,1\% dos estudos, as intervenções foram efetivas para a mudança do comportamento para realizar AF, porém, poucas foram baseadas em teoria. A diversidade das populações alvo, dos instrumentos de avaliação e das intervenções dificulta a comparação dos resultados e a construção de evidências sobre a efetividade de intervenções para a promoção de $A F$.

DESCRITORES: atividade motora; comportamento; estudos de intervenção

${ }^{1}$ RN, M.Sc., Faculdade de Ciências Médicas, Universidade Estadual de Campinas, Brazil. ${ }^{2}$ RN, Associate Professor, Faculdade de Ciências Médicas, Universidade Estadual de Campinas, Brazil, e-mail: robertar@fcm.unicamp.br, ceciliag@fcm.unicam. ${ }^{3}$ RN, Hospital e Maternidade Celso Pierro, Pontifícia Universidade Católica de Campinas, Brazil, e-mail: laurabacelar@uol.com.br. ${ }^{4} \mathrm{RN}$, Doctoral Student, Faculdade de Ciências Médicas, Universidade Estadual de Campinas, Brazil, e-mail: titodrm@yahoo.com.br. 


\section{INTRODUCTION}

$\boldsymbol{R}$ egular physical activity (PA) results in systemic benefits, such as a lower heart frequency, increased cardiac debit and decreased blood pressure. The effects of physical exercise are not only related to the biological sphere, but also to its positive effects on psychological and psychosocial health ${ }^{(1)}$. Adherence to physical exercise programs aiming for health promotion is low in the general population, representing a major public health concern. Countless personal and environmental factors are implied in how demographic, biological, psychological, social and physical factors are related to the program. Strategies need to be developed that make people adopt a more active lifestyle, knowing, preventing and/or controlling the risk factors present in their lifestyle ${ }^{(2)}$. Changes in health behavior result from reciprocal relations between the environment, personal factors and behavioral attributes ${ }^{(3)}$. Considering the importance of adopting a more active lifestyle, nurses, as one of the categories responsible for educative activities with the healthy or ill population, need to develop, put in practice and assess the effectiveness of interventions aimed at optimizing regular PA practice and, consequently, a healthier lifestyle.

\section{OBJECTIVES}

This study aimed to carry out an integrative review of Brazilian and international literature about the design and effectiveness of interventions used to stimulate PA practice in different population groups.

\section{METHODS}

The steps recommended by literature were used to elaborate the integrative review ${ }^{(4-5)}$.

Identification of review problem

The following guiding question was chosen: What is the design and effectiveness of behavioral interventions to promote physical activity in the general population?

Sample selection

Articles in English or Brazilian Portuguese were considered eligible if published in journals indexed in Medical Literature Analysis and Retrieval
System on-line (MEDLINE, PubMed version), Cumulative Index to Nursing and Allied Health Literature (CINAHL) and SCOPUS, between August 2004 and August 2008, departing from the descriptors Intervention Studies, Motor Activity and Behavior, according to the Medical Subject Headings (MeSH), and their equivalents in Brazilian Portuguese according to the Health Sciences Descriptors (DeCS). The search was carried out in the three databases at the same time, in September 2008, using the descriptors combined by the Boolean connector "AND". As a result, 102 articles were found: 64 in SCOPUS, 26 in MEDLINE and 12 in CINAHL. The titles and abstracts of these 102 articles were carefully read, 40 were excluded because they were inadequate for the guiding questions, 3 were duplicates (found in more than one database), 15 were not available online in their full version in the collection of the University's Library System and 16 were meta-analyses or reviews. Twenty-eight articles were selected for analysis of their full version, including articles with evidence level 2 (individual research with experimental design) or 3 (research with quasi-experimental design) ${ }^{(6)}$. The final sample consisted of 14 articles $^{(7-20)}$, in compliance with literature, which recommends that at least $30 \%$ of articles attending to the established inclusion criteria be included ${ }^{(5)}$.

Study categorization, analysis and interpretation

A specific instrument was used to assess articles for inclusion in reviews, which Ursi constructed and validated in an earlier study ${ }^{(21)}$. The analysis of the articles was based on the concepts of quantitative research with experimental and quasi-experimental designs $^{(22)}$ and on literature about the research theme ${ }^{(5)}$.

\section{RESULTS}

Most studies (64\%) are indexed in SCOPUS, in journals within the theme area Health Sciences, particularly Medicine (28.5\%), followed by Oncology (21.4\%), Metabolism, Psychology and Nutrition Sciences $(21.4 \%)$; Geriatrics $(14.3 \%)$ and Public Health $(14.3 \%)$; with an average impact factor of $3.7( \pm 3.9)$. Half of the production comes from the United States, followed by Europe (21.4\%), Australia (21.4\%) and Canada (7.1\%); $57.1 \%$ of studies were 
developed at universities, $35.7 \%$ in multicenter research centers and $7.1 \%$ in hospitals. Homogeneous distribution was found between experimental and quasi-experimental studies (50\%, respectively), predominantly randomization $(64.3 \%)$ and control group $(85.7 \%)$. The mean sample size was $452( \pm 518)$ subjects. Most studies (78.6\%) covered male and female subjects, $14.3 \%$ did not inform the participants' gender and $7.1 \%$ included women only. Great variation in subjects' age range was observed, with most studies including adults and/or elderly.

The result was assessed through PA questionnaires, objective PA measures (physical capacity, pedometer, accelerometer), or by behavioral variables (motivation, self-efficacy, stages of change), or by symptom perception (fatigue). Psychometric scales to measure motivation, fatigue and perceived effort stood out, as well as to measure psychosocial variables knowingly influenced by PA, as evidenced in other review studies ${ }^{(23-24)}$. Instruments were frequently used to quantify the duration, intensity and frequency of PA. Most studies (64.3\%) used biological markers, such as maximum oxygen consumption, serum cholesterol levels and body mass index (BMI) $)^{(7,11,14-}$ ${ }^{19,20)}$ and half of them applied physical tests, such as load and walking tests ${ }^{(8,11,14-15,17-18,20)}$ (Table 1).

In half of the studies, the intervention was based on a theoretical framework: $28.6 \%$ was based on Motivational Theories and $21.4 \%$ on Multiple-Stage Models (Table 3). A majority (71.4\%) used the isolated increase in PA as the dependent variable, with walking as the most explored target behavior, followed by the association between PA and healthy eating (28.6\%), and between PA, healthy eating and giving up smoking $(7.1 \%)$. The mean duration of interventions was $37.9( \pm 23.3)$ weeks, with a minimum duration of 8 and a maximum of 72 weeks. The methodology was considered appropriate in $42.8 \%$ of the studies ${ }^{(10-}$ 11,15,19-20), considering criteria as viability, reproducibility, method clarity and application of instruments and objective measures; in $14.3 \%$, the design of the steps was not clear, impeding reproducibility ${ }^{(13,16)}$; and, in $28.6 \%$, no criteria were mentioned for including/excluding subjects. In data analysis, parametric $(42.8 \%)$ and variance and covariance $(42.8 \%)$ models predominated.

The interventions were effective to promote PA behavior in $57.1 \%(n=8)$ of the analyzed studies and ineffective in $14.3 \%(n=2)^{(7,13)}$. The result of the intervention was not reported in $28.6 \%(n=4)$ of the studies $^{(12,15,18-19)}$. In the eight studies in which the intervention was considered effective, the assessed outcome was increased PA frequency $(75 \%, n=6)^{(9-}$ $11,14,16,20)$, increased PA frequency associated with another behavior $(7.1 \% ; n=1)^{(17)}$ and improved Quality of Life (QoL) and muscle force $(7.1 \% ; n=1)^{(14)}$. No negative effects of the interventions were reported on.

\section{DISCUSSION}

The findings evidence that most of the publications on PA interventions has been disseminated in journals from the Health Science Area, classified in different subjects.

Table 1 - List of PA measurement instruments, tests and variables measured in the studies included in the integrative review. Campinas, 2009

\begin{tabular}{|c|c|c|}
\hline PA measurement instruments & Variable measured & Reference \\
\hline \multicolumn{3}{|l|}{ Measurement of psychosocial determinants of behavior } \\
\hline Treatment Self-Regulation Questionnaire (TSRQ) & Motivation & Fortier et al., $2007^{(18)}$ \\
\hline $\begin{array}{l}\text { Behavioural Regulation In Exercise Questionnaire } \\
\text { (BREQ-2) }\end{array}$ & Behavioral Regulation & Fortier et al., $2007^{(18)}$ \\
\hline Godin leisure-time exercise questionnaire (GLTEQ) & Exercise habits in leisure time & $\begin{array}{l}\text { Fortier et al., } 2007^{(18)} \text { Williams et al., } \\
2004^{(19)}\end{array}$ \\
\hline Stage of Motivational Readiness for Physical Activity & Self-efficacy and motivation for PA practice & Pinto et al., $2005^{(11)}$ \\
\hline $\begin{array}{l}\text { Stage of Change for regular exercise (SoC for regular } \\
\text { exercise) }\end{array}$ & $\begin{array}{l}\text { Pre-Contemplation, Contemplation, Preparation, } \\
\text { Action and Maintenance Stages }\end{array}$ & Clark et al., $2005^{(13)}$ \\
\hline \multicolumn{3}{|l|}{ Measurement of objective variables } \\
\hline Up-and-Go & PA intensity/frequency & Clark et al., $2005^{(13)}$ \\
\hline Seven-day Physical Activity Recall (7-Day PA Recall) & PA duration, intensity and energy consumption & Pinto et al., $2005^{(11)}$ \\
\hline Yale Physical Activity Survey (YPAS) & PA intensity/frequency & Clark et al., $2005^{(13)}$ \\
\hline International Physical Activity Questionnaire (IPAQ) & Habitual PA levels in general population & Spittaels et al., $2007^{(9)}$ \\
\hline Adolescent Physical Activity Questionnaire (APAQ) & PA levels during leisure time & Lubans and Morgan, $2008^{(10)}$ \\
\hline
\end{tabular}


Table 1 - Continuation

\begin{tabular}{|c|c|c|}
\hline PA measurement instruments & Variable measured & Reference \\
\hline \multicolumn{3}{|l|}{ Measurement of perceived symptom to effort } \\
\hline Multidimensional Fatigue Inventory (MFI) & Fatigue & De Backer et al., $2008^{(14)}$ \\
\hline Rating of Perceived Exertion (RPE) & Perceived effort caused by exercise & De Backer et al., $2008^{(14)}$ \\
\hline Fatigue Scale & Fatigue & Clark et al., $2005^{(13)}$ \\
\hline \multicolumn{3}{|l|}{ Physical tests } \\
\hline One maximum strength test (1-RM Test) & $\begin{array}{l}\text { Maximum resistance burden for a series of } \\
\text { repetitions of a given exercise }\end{array}$ & De Backer et al., 2008 ${ }^{(14)}$ \\
\hline Rockport 1-mile Walk Test & Predicts aerobic capacity in a walk mile & Pinto et al., 2005(11) \\
\hline Pedometer & Number of steps walked & $\begin{array}{l}\text { Hyman et al., } 2007^{(17) ;} \text { Mahar et al., } \\
2006^{(8)} \text {; Beresford et al., } 2007^{(20)}\end{array}$ \\
\hline Accelerometer & $\begin{array}{l}\text { Linear pulse acceleration degree, total body } \\
\text { movement and degree of PA }\end{array}$ & $\begin{array}{l}\text { Fortier et al., } 2007^{(18) ;} \text { Pinto et al., } \\
2005^{(11)}\end{array}$ \\
\hline Exercise Test (6' and 12') & Maximum oxygen consumption - VO2 & $\begin{array}{l}\text { Fortier et al., } 2007^{(18)} \text {; Spence et al., } \\
2007^{(15) ;} \text { De Backer et al., } 2008^{(14)}\end{array}$ \\
\hline
\end{tabular}

None of the studies was found in nursing journals, which evidences the need for nursing research in this area. The methodological design showed incoherence in terms of sampling process, as well as lack of clarity in the intervention phases. These findings are consistent with other reviews ${ }^{(23-24)}$. The mean follow-up period coincided with the duration of the intervention, indicating the need for longitudinal designs, with a view to evidence on the long-term effectiveness of the intervention.

In half of the studies analyzed, strategies were theory-based, especially motivational theories. However, among the $57.1 \%$ whose results evidenced a significant increase in PA, strategies had been theory-based in only $28.6 \%$, corresponding to a mere $14.3 \%$ of the sample. Nowadays, there is a largescale debate among experts about the utility and perceived barriers in the application of behavioral theories ${ }^{(23-25)}$. These theories point towards a generalized and carefully interpreted systematic summary of empirical evidence on behavior, and its application is expected to improve the effectiveness of interventions for behavioral modification. It has been argued, however, that most theories offer important support as to which needs should be changed, and not how these changes can be induced ${ }^{(26)}$. Hence, it would be important for theories, besides explaining the subject's motivation to adopt the behavior, to advance in knowledge about how behavioral determinants of change can be modified and how these determinants can be translated into methods, strategies and effective instruments for behavioral change ${ }^{(26)}$. The diversity of the target population, the intervention methods and assessment measures used, as well as the lack of standardization in self-reports on PA in the studies under analysis, limit the identification of which of strategies' potential attributes are associated with the effectiveness of an intervention.

Table 2 - Synthesis of physical activity promotion interventions described in the articles included in the integrative review. Campinas, 2009

\begin{tabular}{|c|c|c|c|c|c|c|c|c|c|}
\hline Reference & $\begin{array}{l}\text { Level of } \\
\text { Evidence }\end{array}$ & Target Group & $\begin{array}{l}\text { Sample } \\
\text { Selection }\end{array}$ & $\begin{array}{c}\text { Sample } \\
\text { Size }\end{array}$ & $\begin{array}{c}\text { Target } \\
\text { Behavior }\end{array}$ & $\begin{array}{c}\text { Theoretical } \\
\text { Reference } \\
\text { Framework }\end{array}$ & Description of Intervention & $\begin{array}{l}\text { Obtained } \\
\text { Measures }\end{array}$ & $\begin{array}{l}\text { Effectiveness of } \\
\text { intervention to } \\
\text { change behavior }\end{array}$ \\
\hline $\begin{array}{l}\text { Holland et } \\
\text { al., } 2005^{(7)}\end{array}$ & 2 & $\begin{array}{l}\text { Elderly with } \\
\text { one or more } \\
\text { chronic health } \\
\text { conditions }\end{array}$ & Random & $n=504$ & $\begin{array}{l}\text { Walking, } \\
\text { swimming, } \\
\text { water } \\
\text { gymnastics, } \\
\text { cycling or other } \\
\text { aerobic activity }\end{array}$ & Not described & $\begin{array}{l}\text { The sample was randomized in a } \\
\text { Control ( } \mathrm{n}=249 \text { ) and Intervention } \\
\text { ( } \mathrm{n}=255 \text { ) group, submitted to the } \\
\text { Health Matters Program, with } \\
\text { telephone contacts every } 4 \text { weeks } \\
\text { and an interview after } 6 \text { months. } \\
\text { During interviews, health action } \\
\text { (behavioral changes to achieve } \\
\text { healthy habits) and fitness (aerobic } \\
\text { exercise program) planning was } \\
\text { elaborated. In follow-up, visits and } \\
\text { telephone contacts to reinforce } \\
\text { and maintain planning. Duration: } \\
24 \text { weeks. }\end{array}$ & $\begin{array}{l}\text { BMI, presence of } \\
\text { chronic health } \\
\text { conditions; minutes } \\
\text { spent on aerobic } \\
\text { activity and } \\
\text { stretching during } \\
\text { last week; social } \\
\text { activities during last } \\
\text { week; social } \\
\text { limitations during } \\
\text { last four weeks; } \\
\text { concerns with } \\
\text { health, pain, fatigue } \\
\text { and dyspnea during } \\
\text { last two weeks. }\end{array}$ & $\begin{array}{l}\text { Increase in minutes } \\
\text { per week spent on } \\
\text { aerobic activities, } \\
\text { stretching and } \\
\text { social visits }(p<0.1) \text {; } \\
\text { decreased } \\
\text { depression } \\
\text { ( } p=0.63 \text { ), concern } \\
\text { and limitations due } \\
\text { to health }(p=0.23) \text {. }\end{array}$ \\
\hline
\end{tabular}


Table 2 - Continuation

\begin{tabular}{|c|c|c|c|c|c|c|c|c|c|}
\hline Reference & $\begin{array}{l}\text { Level of } \\
\text { Evidence }\end{array}$ & Target Group & $\begin{array}{l}\text { Sample } \\
\text { Selection }\end{array}$ & $\begin{array}{c}\text { Sample } \\
\text { Size }\end{array}$ & $\begin{array}{c}\text { Target } \\
\text { Behavior }\end{array}$ & $\begin{array}{l}\text { Theoretical } \\
\text { Reference } \\
\text { Framework }\end{array}$ & Description of Intervention & $\begin{array}{l}\text { Obtained } \\
\text { Measures }\end{array}$ & $\begin{array}{l}\text { Effectiveness of } \\
\text { intervention to } \\
\text { change behavior }\end{array}$ \\
\hline $\begin{array}{l}\text { Mahar et al., } \\
2006^{(8)}\end{array}$ & 2 & $\begin{array}{l}\text { General } \\
\text { population; } \\
\text { children } \\
\text { between } 5 \text { and } \\
11 \text { years }\end{array}$ & Random & $n=243$ & $\begin{array}{l}\text { Moving and } \\
\text { walking }\end{array}$ & Not described & $\begin{array}{l}\text { Sample of students from two } \\
\text { classes in each year, equivalent to } \\
\text { Basic Education, divided in two } \\
\text { groups: } 1 \text { ) Energizers classroom- } \\
\text { based PA Program ( } n=135): 10 \text { ' of } \\
\text { games, play and aerobic PA per } \\
\text { day for } 12 \text { weeks, led by previously } \\
\text { trained instructor; and } 2 \text { ) } \\
\text { Energizers Training }(n=108) \text { : } \\
\text { counseling on childhood obesity } \\
\text { and importance of regular PA } \\
\text { practice. Duration: } 12 \text { weeks. }\end{array}$ & $\begin{array}{l}\text { Number of steps } \\
\text { (pedometer). }\end{array}$ & $\begin{array}{l}\text { Increase in number } \\
\text { of steps in Group } 1 \\
(p<0.05) .\end{array}$ \\
\hline $\begin{array}{l}\text { Spittaelset } \\
\text { al., } 2007^{(9)}\end{array}$ & 3 & $\begin{array}{l}\text { General } \\
\text { population; } \\
\text { adults (not } \\
\text { elderly) }\end{array}$ & Random & $n=285$ & $\begin{array}{l}\text { PA not } \\
\text { specified }\end{array}$ & TPB $^{*}$ & $\begin{array}{l}\text { Sample distribution in } 3 \text { groups, } \\
\text { with application of on-line } \\
\text { questionnaire through the study } \\
\text { site, upon first contact and six } \\
\text { months later. Groups } 1 \text { ( } n=173 \text { ) } \\
\text { and } 2 \text { ( } n=129 \text { ) received counseling } \\
\text { for PA practice based on their } \\
\text { answers. After counseling, Group } 1 \\
\text { was followed by e-mail for } 32 \\
\text { weeks. Group } 3 \text { ( } n=132 \text { ) did not } \\
\text { receive counseling before } 6 \\
\text { months after the start of the study. } \\
\text { Duration: } 24 \text { weeks. }\end{array}$ & $\begin{array}{l}\text { Frequency and } \\
\text { duration of physical } \\
\text { activities at work, } \\
\text { during leisure time } \\
\text { and locomotion; } \\
\text { sitting time per day. } \\
\end{array}$ & $\begin{array}{l}\text { Increase in PA } \\
\text { levels and decrease } \\
\text { in sitting time in } \\
\text { groups } 1 \text { and } 2 \text {, in } \\
\text { comparison with } \\
\text { group } 3(p<0.01) \text {. }\end{array}$ \\
\hline $\begin{array}{l}\text { Lubans and } \\
\text { Morgan, } \\
2008^{(10)}\end{array}$ & 3 & $\begin{array}{l}\text { General } \\
\text { population; } \\
\text { adolescents } \\
\text { between } 12 \\
\text { and } 16 \text { years } \\
\text { of age }\end{array}$ & $\begin{array}{l}\text { Convenie- } \\
\text { nce }\end{array}$ & $n=116$ & $\begin{array}{l}\text { Running, } \\
\text { walking, } \\
\text { cycling }\end{array}$ & & $\begin{array}{l}\text { The Control ( } n=66 \text { ) group was } \\
\text { submitted to counseling about PA; } \\
\text { the Intervention ( } n=50 \text { ) group was } \\
\text { submitted to weekly } 70 \text { ' sessions } \\
\text { of aerobic exercises (gymnastics), } \\
\text { including } 15^{\prime} \text { of counseling and } 55^{\prime} \\
\text { of PA, Duration: } 8 \text { weeks. }\end{array}$ & $\begin{array}{l}\text { Number of steps/ } \\
\text { minutes/day spent } \\
\text { on PA (moderate to } \\
\text { strong); hours/day } \\
\text { spent watching } \\
\text { television, using the } \\
\text { computer or } \\
\text { electronic games. }\end{array}$ & $\begin{array}{l}\text { Significant increase } \\
\text { in PA levels in } \\
\text { Intervention group in } \\
\text { comparison with } \\
\text { Control group } \\
(p<0.05) \text {. }\end{array}$ \\
\hline $\begin{array}{l}\text { Pinto et al., } \\
2005^{(11)}\end{array}$ & 2 & $\begin{array}{l}\text { Adults and } \\
\text { elderly with } \\
\text { cancer }\end{array}$ & Random & $n=86$ & $\begin{array}{l}\text { Moving and } \\
\text { walking }\end{array}$ & Not described & $\begin{array}{l}\text { Control }(n=43) \text { group submitted to } \\
\text { usual measures and Intervention } \\
(\mathrm{n}=43 \text { ) group submitted to } \\
\text { counseling about how to exercise, } \\
\text { monitor } C F, \text { warming up and } \\
\text { walking for } 10^{\prime} \text {, twice/week, until } \\
\text { reaching } 30^{\prime} \text {, five times/week. } \\
\text { Weekly telephone contact for } \\
\text { encouragement, with feedback to } \\
\text { participants during the } 2 \text { nd, } 4 \text { th, } \\
\text { 8th and } 12 \text { th week. Maintenance of } \\
\text { telephone contact for } 3 \text { months } \\
\text { after the end of the program. } \\
\text { Duration: } 48 \text { weeks. }\end{array}$ & $\begin{array}{l}\text { BMl; cutaneous } \\
\text { folds; hours spent } \\
\text { on sleeping and PA } \\
\text { during last week; } \\
\text { maximum speed } \\
\text { reached to walk } \\
1.6 \mathrm{~km} \text {; motivation to } \\
\text { perform PA; number } \\
\text { of steps } \\
\text { (pedometer); } \\
\text { degree of linear } \\
\text { pulse acceleration, } \\
\text { total body } \\
\text { movement and } \\
\text { degree of PA } \\
\text { (accelerometer); } \\
\text { mood; fatigue and } \\
\text { body esteem. }\end{array}$ & $\begin{array}{l}\text { Intervention group } \\
\text { practiced more } \\
\text { minutes of PA per } \\
\text { day, with increase in } \\
\text { number of steps; } \\
\text { presented } \\
\text { increased } \\
\text { motivation to } \\
\text { practice PA, greater } \\
\text { mood variation and } \\
\text { lesser fatigue in } \\
\text { relation to Control } \\
\text { group }(p=0.001) \text {. }\end{array}$ \\
\hline $\begin{array}{l}\text { Harris et al., } \\
2005^{(12)}\end{array}$ & 3 & $\begin{array}{l}\text { General } \\
\text { population, } \\
\text { does not } \\
\text { specify health } \\
\text { conditions or } \\
\text { age }\end{array}$ & $\begin{array}{l}\text { Convenie- } \\
\text { nce }\end{array}$ & - & $\begin{array}{l}\text { Increase health } \\
\text { professionals' } \\
\text { skills to } \\
\text { promote } \\
\text { different PA }\end{array}$ & Not described & $\begin{array}{l}\text { Professionals (physicians, nurses) } \\
\text { from health clinics submitted to } \\
\text { questionnaires to asses their } \\
\text { knowledge and practice in offering } \\
\text { and assessing PA interventions for } \\
\text { patients with risk factors for SNAP } \\
\text { (Smoking, Nutrition, Alcohol and } \\
\text { Physical Activity). Motivational } \\
\text { interviews and training sessions on } \\
\text { practice, barriers and facilitators } \\
\text { for the program. Duration: not } \\
\text { described. }\end{array}$ & $\begin{array}{l}\text { Practical capacity to } \\
\text { put in practice } \\
\text { SNAP intervention; } \\
\text { knowledge of } \\
\text { practices to assess } \\
\text { and offer } \\
\text { interventions for } \\
\text { patients with SNAP } \\
\text { risk factors. }\end{array}$ & $\begin{array}{l}\text { Unpublished results } \\
\text { (study protocol). }\end{array}$ \\
\hline $\begin{array}{l}\text { Clark et al., } \\
2005^{(13)}\end{array}$ & 3 & $\begin{array}{l}\text { General } \\
\text { population; } \\
\text { elderly }\end{array}$ & $\begin{array}{l}\text { Convenie- } \\
\text { nce }\end{array}$ & $n=1274$ & $\begin{array}{l}\text { Unspecified } \\
\text { PA, improve } \\
\text { fruit and } \\
\text { vegetable } \\
\text { consumption }\end{array}$ & $\begin{array}{l}\text { Transtheoretic- } \\
\text { al Change } \\
\text { Theory }\end{array}$ & $\begin{array}{l}\text { Sample submitted to SENIOR } \\
\text { (Study of Exercise and Nutrition in } \\
\text { Older Rhode Islanders Project), } \\
\text { who received a manual on PA. } \\
\text { Follow-up through letters and } \\
\text { telephone interviews every } 4 \\
\text { months. Duration: } 48 \text { weeks. }\end{array}$ & $\begin{array}{l}\text { Perceived Health } \\
\text { Status; time spent } \\
\text { on PA at work, } \\
\text { exercise and } \\
\text { recreation; stage of } \\
\text { change to practice } \\
\text { PA; functional } \\
\text { mobility; fruit and } \\
\text { vegetable } \\
\text { consumption. }\end{array}$ & $\begin{array}{l}\text { Most subjects in } \\
\text { Pre-Contemplation } \\
\text { stage - no intention } \\
\text { to change behavior. } \\
\text { Non-effective } \\
\text { intervention. }\end{array}$ \\
\hline $\begin{array}{l}\text { De Backer } \\
\text { et al., } \\
2008^{(14)}\end{array}$ & 2 & $\begin{array}{l}\text { Adults and } \\
\text { elderly with } \\
\text { cancer }\end{array}$ & Random & $\mathrm{n}=71$ & $\begin{array}{l}\text { Resistance } \\
\text { training }\end{array}$ & Not described & $\begin{array}{l}\text { Control ( } n=22 \text { ) group submitted to } \\
\text { usual care and Intervention ( } n=49 \text { ) } \\
\text { group submitted to } 18 \text { weeks of } \\
\text { resistance training and ergometric } \\
\text { bicycle (supervised), after six } \\
\text { weeks of chemotherapy. } \\
\text { Frequency twice per week during } \\
\text { first } 12 \text { weeks. Frequency once } \\
\text { per week during last } 6 \text { weeks. } \\
\text { Assessment every } 4 \text { weeks. At the } \\
\text { end of follow-up, counseling to } \\
\text { keep up PA at home (during } 5 \\
\text { encounters). } \\
\text { Duration: } 68 \text { weeks. }\end{array}$ & $\begin{array}{l}\text { Muscle force; } \\
\text { cardiopulmonary } \\
\text { function; fatigue and } \\
\text { health-related quality } \\
\text { of life. }\end{array}$ & $\begin{array}{l}\text { Intervention group } \\
\text { presented greater } \\
\text { muscle force and } \\
\text { better quality of life } \\
(p<0.01) \text {. }\end{array}$ \\
\hline
\end{tabular}


Table 2 - Continuation

\begin{tabular}{|c|c|c|c|c|c|c|c|c|c|}
\hline Reference & $\begin{array}{l}\text { Level of } \\
\text { Evidence }\end{array}$ & Target Group & $\begin{array}{l}\text { Sample } \\
\text { Selection }\end{array}$ & $\begin{array}{c}\text { Sample } \\
\text { Size }\end{array}$ & $\begin{array}{c}\text { Target } \\
\text { Behavior }\end{array}$ & $\begin{array}{l}\text { Theoretical } \\
\text { Reference } \\
\text { Framework }\end{array}$ & Description of Intervention & $\begin{array}{l}\text { Obtained } \\
\text { Measures }\end{array}$ & $\begin{array}{l}\text { Effectiveness of } \\
\text { intervention to } \\
\text { change behavior }\end{array}$ \\
\hline $\begin{array}{l}\text { Spencer et } \\
\text { al., } 2007^{(15)}\end{array}$ & 2 & $\begin{array}{l}\text { Patients with } \\
\text { cancer; not } \\
\text { specified }\end{array}$ & Random & $\begin{array}{c}\text { Not } \\
\text { informed }\end{array}$ & $\begin{array}{l}\text { Aerobics } \\
\text { exercise } \\
\text { session }\end{array}$ & Not described & $\begin{array}{l}\text { Random sample with Control and } \\
\text { Intervention group. Intervention } \\
\text { group submitted to aerobic } \\
\text { exercise sessions } 3 \text { times per } \\
\text { week, during } 12 \text { weeks, with } \\
\text { supervision by physiologist. Initial } \\
\text { duration } 20^{\prime} \text { and light intensity, with } \\
\text { gradual increase to } 40^{\prime} \text { and high } \\
\text { intensity (modified across follow- } \\
\text { up). } \\
\text { Duration: } 12 \text { weeks. }\end{array}$ & $\begin{array}{l}\text { Cardiorespiratory } \\
\text { capacity with 6- } \\
\text { minute walking test; } \\
\text { measurement of } \\
\text { fatigue and QoL } \\
\text { Insulin } 1 \text { Growth } \\
\text { Factor (IGF-1) and } \\
\text { Insulin-like growth } \\
\text { factor binding } \\
\text { protein (IGFBP-3) } \\
\text { dosage. }\end{array}$ & $\begin{array}{l}\text { Unpublished results } \\
\text { (study protocol) }\end{array}$ \\
\hline $\begin{array}{l}\text { Spiegel and } \\
\text { Foulk , } \\
2006^{(16)}\end{array}$ & 2 & $\begin{array}{l}\text { General } \\
\text { population; } \\
\text { children } \\
\text { between } 5 \text { and } \\
\text { 11years }\end{array}$ & Random & $\mathrm{n}=1013$ & $\begin{array}{l}\text { Unspecified } \\
\text { PA; improve } \\
\text { fruit and } \\
\text { vegetable } \\
\text { consumption }\end{array}$ & $\begin{array}{c}\text { Rational } \\
\text { Action Theory } \\
\end{array}$ & $\begin{array}{l}\text { Control group ( } \mathrm{n}=478 \text { ) submitted to } \\
\text { usual care and Intervention group } \\
\text { ( } \mathrm{n}=529 \text { ) submitted to WAY*, } \\
\text { divided into modules: } 1=\text { concept } \\
\text { of well-being, orientation about } \\
\text { Intention and Subjective Standards; } \\
2=\text { orientations to register } \\
\text { physiological data and PA levels } \\
\text { (scales); } 3=\text { principles for PA } \\
\text { practice, establishing and } \\
\text { incorporating exercise routine; } 4= \\
\text { classes about nutrition; } 5= \\
\text { functioning of human body; } 6= \\
\text { genetics and family history and } 7= \\
\text { students verbally reproduce what } \\
\text { they learned to relative and } \\
\text { register how this approach took } \\
\text { place. Availability of DVD and } \\
\text { website to support activities. } \\
\text { Duration: } 28 \text { weeks. }\end{array}$ & $\begin{array}{l}\text { Fruit and vegetable } \\
\text { consumption; } \\
\text { frequency of PA } \\
\text { practice; BMI. } \\
\end{array}$ & $\begin{array}{l}\text { Increased fruit and } \\
\text { vegetable } \\
\text { consumption in both } \\
\text { groups, more } \\
\text { significant in } \\
\text { Intervention group. } \\
\text { Increase in PA } \\
\text { levels in Intervention } \\
\text { group }(p=0.05) \text {. }\end{array}$ \\
\hline $\begin{array}{l}\text { Hyman et al., } \\
2007^{(17)}\end{array}$ & 3 & $\begin{array}{l}\text { Hypertensive } \\
\text { adults and } \\
\text { elderly }\end{array}$ & $\begin{array}{l}\text { Convenie- } \\
\text { nce }\end{array}$ & $\mathrm{n}=230$ & $\begin{array}{l}\text { Walking, stop } \\
\text { smoking and } \\
\text { decreasing } \\
\text { sodium } \\
\text { consumption }\end{array}$ & Not described & $\begin{array}{l}\text { Sample divided in } 3 \text { groups: } \\
\text { Group } 1 \text { ( } n=92) \text { : simultaneous } \\
\text { counseling for three target } \\
\text { behaviors, Group } 2 \text { ( } n=96) \text { : } \\
\text { sequential counseling for three } \\
\text { target behaviors; Group } 3 \text { ( } n=93) \text { : } \\
\text { control. Personal meeting every } 6 \\
\text { months, with seven telephone } \\
\text { contacts during interval. Duration: } \\
72 \text { weeks. }\end{array}$ & $\begin{array}{l}\text { Creatinine/urinary } \\
\text { sodium; fasting } \\
\text { glucose, glycated } \\
\text { hemoglobin, number } \\
\text { of steps and self- } \\
\text { efficacy. }\end{array}$ & $\begin{array}{l}\text { Simultaneous } \\
\text { approach of three } \\
\text { behaviors was more } \\
\text { effective for sodium } \\
\text { consumption } \\
\text { decrease }(p=0.41) \text {, } \\
\text { PA ( } p=0.03 \text { ) and } \\
\text { giving up smoking } \\
(p=0.02)\end{array}$ \\
\hline $\begin{array}{l}\text { Fortier et al., } \\
2007^{(18)}\end{array}$ & 2 & $\begin{array}{l}\text { General } \\
\text { population; } \\
\text { adults and } \\
\text { elderly }\end{array}$ & Random & $n=120$ & Walking & $\begin{array}{l}\text { Self-Determin- } \\
\text { ation Theory }\end{array}$ & $\begin{array}{l}\text { Control group ( } n=59) \text { : short } \\
\text { counseling for PA practice. } \\
\text { Intervention group ( } n=61) \text { : intensive } \\
\text { counseling for PA. } 1 / 3 \text { from each } \\
\text { group was selected to participate } \\
\text { in physical/metabolic tests. The } \\
\text { program comprises the model of } \\
\text { the "7 As" (Address, Ask, Advise, } \\
\text { Assess/Agree, Assess, Assist, } \\
\text { Arrange). Counseling and personal } \\
\text { assessment during weeks } 3,5,12 \text {, } \\
13 \text { and } 25 \text {. Telephone contact } \\
\text { during weeks } 6,7,9,11 \text { and } 19 \text {. } \\
\text { Metabolic and physical test during } \\
\text { weeks } 2,13 \text { and } 25 \text {. Duration: } 25 \\
\text { weeks. }\end{array}$ & $\begin{array}{l}\text { Motivation; self- } \\
\text { efficacy; degree of } \\
\text { linear pulse } \\
\text { acceleration, total } \\
\text { body movement and } \\
\text { degree of physical } \\
\text { activity } \\
\text { (accelerometer); } \\
\text { Perceived health } \\
\text { state; aerobic } \\
\text { capacity, CF, arterial } \\
\text { pressure, } \\
\text { anthropometric } \\
\text { measures; fasting } \\
\text { glucose, glycated } \\
\text { hemoglobin, serum } \\
\text { lipids and insulin } \\
\text { resistance. }\end{array}$ & Unpublished results. \\
\hline $\begin{array}{l}\text { Williams et } \\
\text { al., 2004(19) }\end{array}$ & 2 & $\begin{array}{l}\text { General } \\
\text { population; } \\
\text { adults (not } \\
\text { elderly) }\end{array}$ & Random & $\mathrm{n}=300$ & $\begin{array}{l}\text { Walking and } \\
\text { each } \\
\text { participant's } \\
\text { preferred } \\
\text { activities }\end{array}$ & TPB & $\begin{array}{l}\text { Random sample in Group } 1 \\
\text { ( } n=120) \text { : interview, face-to-face } \\
\text { counseling program and telephone } \\
\text { follow-up; Group } 2(n=124) \text { : } \\
\text { interview and distance counseling } \\
\text { program and follow-up by letters; } \\
\text { Group } 3 \text { - Control ( } n=121) \text { : short } \\
\text { counseling. Duration: } 52 \text { weeks. }\end{array}$ & $\begin{array}{l}\text { Time per day spent } \\
\text { on PA; energy } \\
\text { consumption by PA; } \\
\text { PA at work, leisure } \\
\text { and in housework; } \\
\text { calorimetry, } \\
\text { maximum O2 } \\
\text { consumption and } \\
\text { CF. }\end{array}$ & Unpublished results. \\
\hline $\begin{array}{l}\text { Beresford et } \\
\text { al., } 2007^{(20)}\end{array}$ & 2 & $\begin{array}{l}\text { General } \\
\text { population, } \\
\text { does not } \\
\text { specify health } \\
\text { conditions or } \\
\text { age }\end{array}$ & Random & $\mathrm{n}=1633$ & $\begin{array}{l}\text { Unspecified } \\
\text { PA, improve } \\
\text { fruit and } \\
\text { vegetable } \\
\text { intake }\end{array}$ & $\begin{array}{l}\text { Social } \\
\text { Learning } \\
\text { Theory }\end{array}$ & $\begin{array}{l}\text { Control ( } n=768 \text { ) and Intervention } \\
\text { ( } n=865) \text { groups, the latter } \\
\text { submitted to the PACE program† - } \\
\text { 1st Phase: creating awareness } \\
\text { about the importance of healthy } \\
\text { eating and PA; 2nd Phase: } \\
\text { motivation/support to improve PA; } \\
\text { 3rd Phase: motivation and support } \\
\text { to improve food intake; 4th Phase: } \\
\text { support system - encourage PA } \\
\text { and healthy food intake; and 5th } \\
\text { Phase: support for maintenance of } \\
\text { PA and diet changes through } \\
\text { social meetings. Duration: } 72 \\
\text { weeks. }\end{array}$ & $\begin{array}{l}\text { Serum cholesterol } \\
\text { levels; BMl; } 24 \mathrm{~h} \\
\text { dietary recall; } \\
\text { number of } \\
\text { steps/week; PA } \\
\text { frequency. }\end{array}$ & $\begin{array}{l}\text { Increased PA levels } \\
\text { in Intervention } \\
\text { group, greater in } \\
\text { women }(p<0.001) \text {. }\end{array}$ \\
\hline
\end{tabular}


Among the $57.1 \%$ of studies with a significant increase in PA, intervention strategies comprised counseling, written information/orientations and didactical material, either separately or jointly, with substantially different application/follow-up periods. These disparities do not permit comparisons and generalization of findings and, consequently, make it more difficult to construct evidence on the effectiveness of the interventions for PA promotion. Although this review involved a limited number of studies, its findings indicate the short-term effectiveness of interventions for PA promotion, in line with results from earlier reviews ${ }^{(24,26)}$. The small number of interventions incorporated into the (health and education) service routine is highlighted, which reveals a continuing gap between theoretical conception and practical application. Interventions with a multidisciplinary approach were also rare, directed at the family's involvement in the adoption of PA practice.

Study limitations

Limitations were related to the exclusive use of DeCS and MeSH descriptors to locate the articles in the electronic databases, which can explain that a limited number of studies was recovered during the period, and also that studies accessed electronically were included, which restricted access to all studies elected for the review.

\section{CONCLUSIONS}

This integrative review about the use of behavioral interventions in the period from August 2004 to August 2008 evidenced that, in $57.1 \%$ of the studies, interventions effectively promoted PA; of these, however, intervention strategies had been based on theory in few studies. The range of assessment instruments and interventions limits comparisons and result generalizations and make it more difficult to construct evidence about the effectiveness of interventions to promote PA in the short and long terms.

\section{REFERENCES}

1. Warburton DER, Nicol CW, Bredin SSD. Health benefits of physical activity: the evidence. Can Med Assoc J 2006 março; 174(6):801-9.

2. Forjaz CLM, Tinucci T. Estratégias de melhora da adesão ao exercício como tratamento não-farmacológico de doenças crônicas. In: Mion Jr D, Nobre F, organizadores. Risco cardiovascular global. São Paulo (SP): Lemos Editorial; 2002. p. 104-37.

3. Sniehotta FF, Scholz U, Schwarzer R. Bridging the intentionbehavior gap: planning, self-efficacy, and action control in the adoption and maintenance of physical exercise. Psychol Health 2005 abril; 20(2):143-60.

4. Mendes KDS, Silveira RCCP, Galvão CM. Revisão integrativa: método de pesquisa para a incorporação de evidências na saúde e na enfermagem. Texto Contexto Enferm 2008 outubro-dezembro; 17(4):758-64.

5. Ganong LH. Integrative reviews of nursing research. Res Nurs Health 1987 fevereiro; 10(1):1-11.

6. Stetler CB, Morsi D, Rucki S, Broughton S, Corrigan B, Fitzgerald J, et al. Clinical methods: utilization-focused integrative reviews in a nursing service. Appl Nurs Res 1998 novembro; 11(4):195-206.

7. Holland SK, Greenberg J, Tidwell L, Malone J, Mullan J, Newcomer R. Community-Based Health Coaching, Exercise, and Health Service Utilization. J Aging Health 2005 dezembro; 17(6):697-716.

8. Mahar MT, Murphy SK, Rowe DA, Golden J, Shields AT, Raedeke TD. Effects of a Classroom-Based Program on
Physical Activity and On-Task Behavior. Med Sci Sports Exerc 2006 dezembro; 38(12):2086-94.

9. Spittaels $H$, Bourdeaudhuij ID, Vandelanotte C. Evaluation of a website-delivered computer-tailored intervention for increasing physical activity in the general population. Prev Med 2007 janeiro; 44(3):209-17.

10. Lubans D, Morgan P. Evaluation of an extra-curricular school sport programme promoting lifestyle and lifetime activity for adolescents. J Sports Sci 2008 novembro; 26(5):519-29.

11. Pinto BM, Frierson GM, Rabin C, Trunzo JJ, Marcus BH. Home-Based Physical Activity Intervention for Breast Cancer Patients. J Clin Oncol 2005 maio; 23(15):3577-87.

12. Harris MF, Hobbs C, Davies GP, Simpson S, Bernard D, Stubbs A. Implementation of a SNAP intervention in two divisions of general practice: a feasibility study. Med J Aust 2005 julho; 183(10):54-8.

13. Clark PG, Rossi JS, Greaney ML, Riebe DA, Greene GW, Saunders SD, et al. Intervening on Exercise and Nutrition in Older Adults: The Rhode Island SENIOR Project. J Aging Health 2005 dezembro; 17(6):753-78.

14. De Backer IC, Vreugdenhil G, Nijziel MR, Kester AD, Breda E van, Schep G. Long-term follow-up after cancer rehabilitation using high-intensity resistance training: persistent improvement of physical performance and quality of life. Br J Cancer 2008 julho; 99(1):30-6.

15. Spence RR, Kristiann C, Heesch KC, Eakin EG, Brown WJ. Randomised controlled trial of a supervised exercise rehabilitation program for colorectal cancer survivors immediately after chemotherapy: study protocol. BMC Cancer 
2007 agosto; 7:154.

16. Spiegel SA, Foulk D. Reducing Overweight through a Multidisciplinary School-based Intervention. Obesity 2006 janeiro; 14(1):88-96.

17. Hyman DJ, Pavlik VN, Taylor WC, Goodrick GK, Moye L. Simultaneous vs Sequential Counseling for Multiple Behavior Change. Arch Intern Med 2007 junho; 167(11):1152-8.

18. Fortier MS, Hogg W, O'Sullivan TL, Blanchard C, Reid RD, Sigal RJ, et al. The Physical Activity Counselling (PAC) randomized controlled trial: rationale, methods, and interventions. Appl Physiol Nutr Metab 2007 dezembro; 32(6):1170-85.

19. Williams K, Prevost AT, Griffin S, Hardeman W, Hollingworth $W$, Spiegelhalter $D$, et al. The ProActive trial protocol - a randomised controlled trial of the efficacy of a family-based, domiciliary intervention programme to increase physical activity among individuals at high risk of diabetes [ISRCTN61323766]. BMC Public Health 2004 outubro; $4: 48$.

20. Beresford SAA, Locke E, Bishop S, West B, McGregor BA, Bruemmer $B$, et al. Worksite Study Promoting Activity and Changes in Eating (PACE): Design and Baseline Results. Obesity 2007 novembro; 15(Suppl 1):4-15.

21. Ursi ES. Prevenção de lesões de pele no perioperatório: revisão integrativa da literatura. [dissertação]. Ribeirão Preto (SP): Escola de Enfermagem de Ribeirão Preto/USP; 2005. 22. Whittemore R, Grey M. Experimental and quasi experimental designs. In: Lobiondo-Wood G, Haber J, editores. Nursing research: methods and critical appraisal for evidencebased practice. Saint Louis (MO): Mosby/Elsevier, 2006. p. 220-37.

23. Hardeman W, Johnston M, Johnston DW, Bonetti D, Wareham NJ, Kinmonth AL. Application of the Theory of Planned Behaviour in behaviour change interventions: a systematic review. Psychol Health 2002 janeiro; 17(2):123-58.

24. Smith BJ. Promotion of physical activity in primary health care: update of the evidence on interventions. J Sci Med Sport 2004 abril; 7(1 Suppl 1):67-73.

25. Pinto CJMP, Colombo RCR, Gallani MCBJ. Nurses' attitudinal and normative beliefs concerning hemodynamic assessement by pulmonary artery catheterization. Rev Latinoam Enfermagem 2006 novembro-dezembro; 14(6):915-22. 26. Brug J, Oenema A, Ferreira I. Theory, evidence and Intervention Mapping to improve behavior nutrition and physical activity interventions. Int $\mathrm{J}$ Behav Nutr and Phys Act [serial online] 2005 abril [citado 3 abril 2009]; 2:2 [7 telas]. Disponível em: URL: http://www.ijbnpa.org/content/ $2 / 1 / 2$ 